\title{
Cervical carcinoma in the setting of uterovaginal prolapse: comparing standard versus tailored management
}

\author{
Ryan M Kahn $^{1 a}$ (iD, Sushmita Gordhandas ${ }^{1}$, Kiersten Craig ${ }^{2}$, Tanaka J Dune ${ }^{2}$, Kevin Holcomb ${ }^{3}$, Eloise Chapman-Davis ${ }^{3}$ and Melissa K Frey ${ }^{3}$ \\ ${ }^{1}$ Department of Obstetrics and Gynecology, Weill Cornell Medicine, New York, NY 10065, USA \\ ${ }^{2}$ Department of Urology, Weill Cornell Medicine, New York, NY 10065, USA \\ ${ }^{3}$ Division of Gynecologic Oncology, Department of Obstetrics and Gynecology, Weill Cornell Medicine, New York, NY 10065, USA \\ ahttp://orcid.org/0000-0002-5596-6238
}

\section{Abstract}

Objectives: Cervical cancer in the setting of uterovaginal prolapse is exceedingly rare. Altered anatomy can complicate treatment of underlying cancer. We first present a rare case of cervical cancer with invasion of uterovaginal prolapse as well as a systematic review of similar reported cases in the literature. The objective of this study was to compare the practice patterns and outcomes regarding cervical cancer with invasion of procidentia.

Methods: We conducted a systematic search of online databases (PubMed, Embase, Medline and the Cochrane Library) from 1990 to 2018 of all the cases of cervical cancer associated with stage III-IV uterovaginal prolapse. Patient demographics, pathology, surgical management, chemotherapy, radiation and disease-free survival were compared.

Results: Fifteen reported cases of cervical cancer in the setting of procidentia were identified (squamous cell carcinoma-14, clear cell carcinoma-1). The mean age at diagnosis was 74 years (range $54-89)$. Thirteen percent $(n=2)$ of cases presented with FIGO stage I disease, $67 \%(n=10)$ with stage II, and $20 \%(n=3)$ with stage III. All cases had stage III-IV uterovaginal prolapse. 73\% (11) were treated surgically including nine patients who underwent vaginal hysterectomy. Among patients who underwent primary surgery, $7 \%$ (1) received adjuvant chemotherapy, 33\% (5) adjuvant radiotherapy and $21 \%$ (3) both adjuvant chemotherapy and radiation. 33\% (5) of surgical cases included procedures to address the pelvic organ prolapse (colpoclesis $(n=3)$, uterosacral suspension $(n=1)$ and anterior posterior repair $(n=1)$ ). Two patients died from the disease within 12 months, one patient died from other causes within 1 month, and the remainder of patients were free of disease at last reported follow-up (Table 1).

Conclusions: Cervical cancer in the setting of stage III-IV uterovaginal prolapse can be managed successfully with standard treatment strategies (primary surgery with adjuvant therapy as necessary versus chemoradiation). When patients are surgical candidates, techniques to address the underlying prolapse can be used for symptomatic improvement.

Keywords: cervical cancer, PD-L1, uterovaginal prolapse, procidentia
Correspondence to: Ryan M Kahn Email: rmk9008@nyp.org

ecancer 2020, 14:1043

https://doi.org/10.3332/ecancer.2020.1043

Published: $13 / 05 / 2020$

Received: 18/01/2020

Publication costs for this article were supported by ecancer (UK Charity number 1176307).

Copyright: $@$ the authors; licensee ecancermedicalscience. This is an Open Access article distributed under the terms of the Creative Commons Attribution License (http:// creativecommons.org/licenses/by/3.0), which permits unrestricted use, distribution, and reproduction in any medium, provided the original work is properly cited. 


\section{Introduction}

Worldwide, cervical cancer accounts for an estimated 528,000 new cancer cases and 266,000 deaths each year [1]. In under-developed regions, cervical cancer is the second most common type of cancer as well as the third most common cause of cancer related deaths [2]. However, in developed countries with increased screening across the population, cervical cancer represents the 11th most common type of cancer and ninth most common cause of cancer related mortality [3]. The American Cancer society estimates about 13,240 new cases of cervical cancer will be diagnosed in the United States in 2018, with approximately 4,170 deaths from the disease [4]. Pelvic organ prolapse is a far more common disease, estimated to occur in roughly $40 \%-60 \%$ of parous women [5]. The association between cervical cancer and uterovaginal prolapse is an exceedingly rare occurrence in developed countries. There has been minimal literature reported with no current guidelines in regards to the treatment. This is a case-report of cervical carcinoma with invasion of stage IV uterine prolapse and lung metastasis with a full systematic review of the current literature on management patterns and outcomes. This is the first reported case of PD-L1 cervical cancer with invasion of uterovaginal prolapse as well as the first reported case undergoing immunotherapy. Additionally, this is the first complete systematic review performed investigating past cases of cervical cancer associated with pelvic organ prolapse.

\section{Case report}

This is a 68 year-old post-menopausal, gravida four para three, with a long standing history of uterovaginal prolapse. The patient was unable to describe the duration of her procidentia but reported that the prolapse began to protrude past the vagina for seven months prior to presentation and has been unable to reduce the mass. The patient then began to note a large malodorous, fungating lesion on the prolapse associated with vaginal bleeding. At time of presentation, physical exam revealed a $14 \mathrm{~cm} \times 10 \mathrm{~cm}$ necrotic mass (Figure 1).

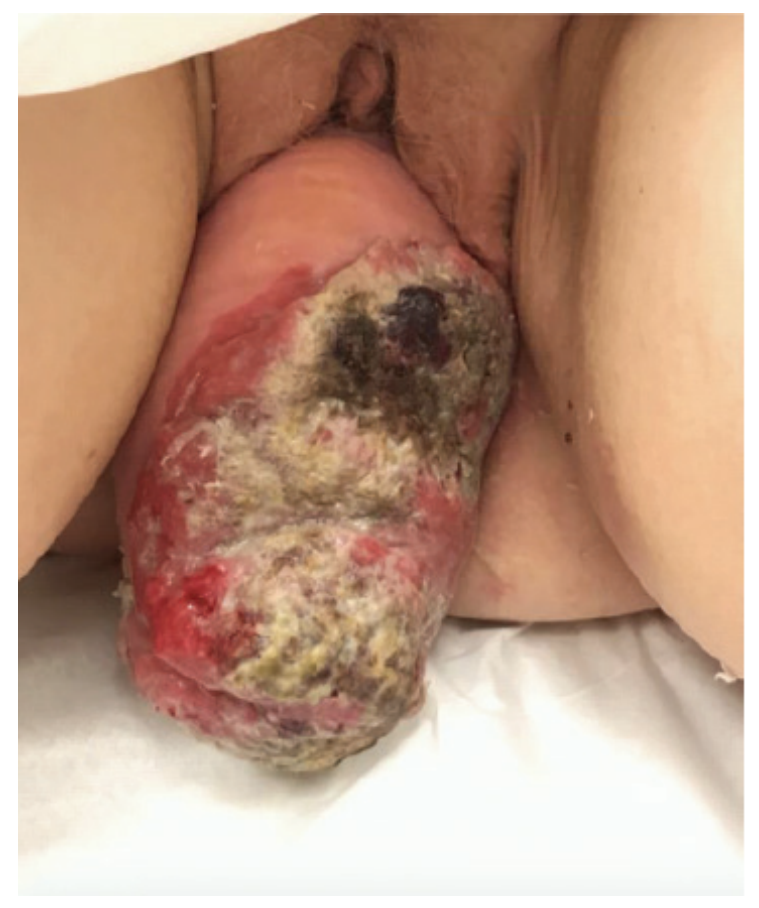

Figure 1. Image of $14 \mathrm{~cm} \times 10 \mathrm{~cm}$ necrotic mass associated with stage 4 uterine prolapse on presentation. 
A biopsy of the lesion was preformed establishing the diagnosis of invasive squamous cell carcinoma, moderately to poorly differentiated, focally keratinising with a background of high-grade intraepithelial lesion. Computed tomography (CT) of the abdomen and pelvis demonstrated prolapse of part of the bladder, entire uterus and vagina with the gonadal vessels extending inferior to the perineum with two noncalcified lung nodules ( $8 \mathrm{~mm}$ right middle lobe, $5 \mathrm{~mm}$ left lower lobe). Follow-up positron emission tomography/computed tomography (PET/CT) showed severe anterior, middle and posterior compartment prolapse with protruded mass with peripheral FDG uptake (Figure 2); hypermetabolic left common iliac, external iliac and obturator lymphadenopathy, few with mild FDG uptake, and mildly FDG avid hilar lymph nodes that are likely reactive.

The patient was diagnosed with stage IIB invasive squamous cell carcinoma of the cervix. Given the finding of PET positive pelvic lymph nodes-along with the size of the tumour-she was not a surgical candidate. The patient underwent four total cycles of weekly Cisplatin 40 $\mathrm{mg} / \mathrm{m}^{2}$ with 16 fractions of pelvic extended field radiation therapy. The evaluation on each office visit demonstrated areas of resolving necrosis with improvement on each subsequent exam. A follow-up PET/CT 2 months after the completion of therapy demonstrated a decrease in degree of hypermetabolic activity associated with cervical mass hypermetabolic pelvic lymphadenopathy with a new $2.7 \mathrm{~cm}$ markedly hypermetabolic right upper lobe nodule suspicious for new metastasis. The patient underwent CT-guided fine-needle aspiration biopsy of the right pulmonary nodule. Pathology demonstrated squamous cell carcinoma, likely metastatic. Immunohistochemistry was p40 positive and strongly p16 positive in support of metastatic disease, HPV was negative. Further testing demonstrated positive PD-L1 and received four cycles of pembrolizumab $200 \mathrm{mg}$. She also began experiencing worsening, persistent lower back pain. MRI of the lumbar spine demonstrated left lumbar vertebral metastasis. The patient died of disease 12 months following diagnosis.

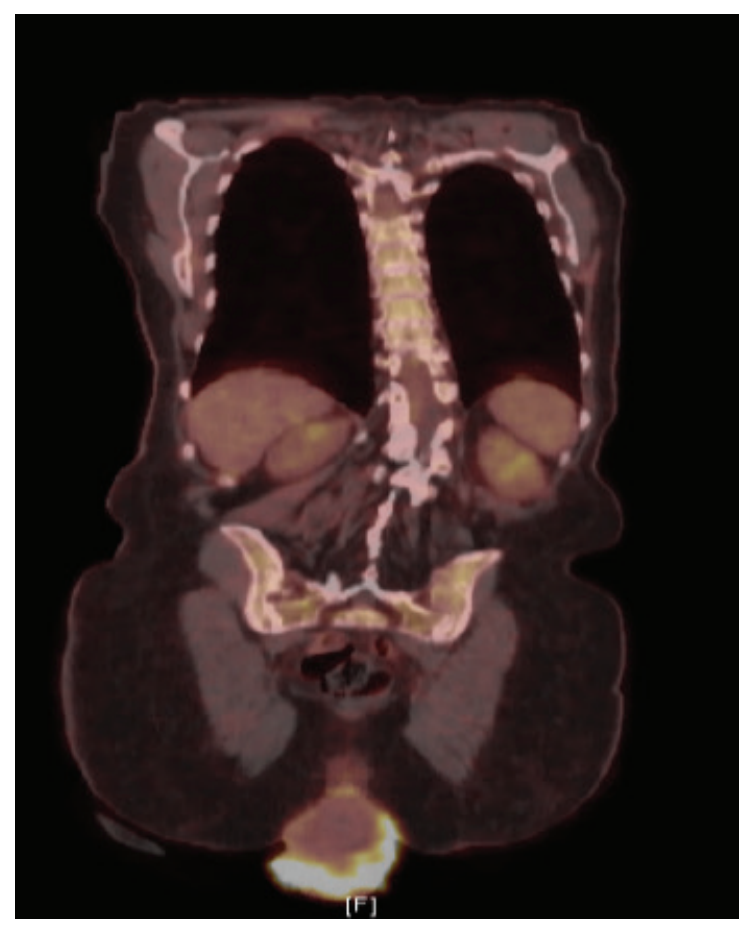

Figure 2. PET/CT demonstrating severe anterior, middle, and posterior compartment prolapse, with protruded mass with peripheral FDG uptake. 


\section{Method}

This study was registered with PROSPERO, the international prospective register of systematic reviews and followed the guidelines set forth by the preferred reporting items for systematic reviews and meta-analyses (PRISMA) statement.[6] A comprehensive literature search was conducted using the following bibliographic databases: Ovid MEDLINE $®$ (In-Process \& Other Non-Indexed Citations and Ovid MEDLINE ${ }^{\circ}$ 1946 to Present), Ovid EMBASE (1974 to present), and The Cochrane Library (Wiley). There were no language, date, or article type restrictions included in the search.

\section{Strategy for search of articles and selection criteria}

This study was registered with PROSPERO, the international prospective register of systematic reviews and followed the guidelines set forth by the PRISMA statement [6]. A comprehensive literature search was conducted by the institutional medical librarian team on January 11, 2018 using the following bibliographic databases from inception: Ovid MEDLINE ${ }$ (In-Process \& Other Non-Indexed Citations and Ovid MEDLINE $\mathbb{R} 1946$ to Present), Ovid EMBASE (1974 to present), and The Cochrane Library (Wiley). No language, publication date or article type restrictions were included in the search.

Data for the number of patients with cervical cancer with pathology confirmed invasion of uterovaginal prolapse was extracted from each study. Additionally, data on age, race, body mass index, family history criteria, tumour stage, tumour grade and histologic type were obtained where available. Data were entered into and exported from the Covidence online software program. Two independent investigators retrieved the data.

Study proportions were pooled and. Patient characteristics (i.e., age, tumour grade, histology, management and outcomes) were averaged over the studies to provide descriptive information. Publication bias was not assessed in this systematic review. All analyses were performed with the use of GraphPad Prism statistical software (Version 8.2.0)

\section{Results}

\section{Discussion}

Tumour invasion of prolapsed uterine corpus is uncommon among cervical cancer cases. Given the lack of reported cases and minimal literature on the topic, uterine corpus tumour invasion is not yet considered as a surgical-pathological risk factor, nor is it considered as a reliable marker for prognosis for women with cervical cancer [7]. A 2017 study by Matsuo et al [7] investigated 30 years of national data and identified 837 (4.9\%) cases of uterine invasion among 17,074 cases of early-stage cervical cancer who underwent hysterectomy, however, none exhibited invasion of pelvic organ prolapse. This study demonstrated that invasion is typically associated with older age, non-squamous histology, high-grade tumours, larger tumour size and node status. Additionally, invasion was associated with a significant decrease in causespecific survival when compared to cases without invasion [7]. Given decreased survival outcome among cervical cancer patients with tumour extension to adjacent organs, this study ultimately shows that uterine corpus invasion likely reflects aggressive tumour behaviour.

Cervical cancer invasion of complete uterovginal prolapse is exceedingly rare in developed countries. One of the first reported cases was in 1958 (Rocker et al), followed by reports in 1963 (Cabaniss et al) and 1972 (Daw et al) We performed a systematic review of PubMed, Embase, Medline and the Cochrane Library. A total of 13 reported cases of cancer association with uterovaginal prolapse were identified between 1990 and 2017. Reports ranged from different countries around the world including Austria, Brazil (two cases), France, Germany, India, Italy, Morocco, Portugal, Spain, Taiwan, Turkey and the United States. Table 1 lists each study with comparison of characteristics, management and outcomes [8-21]. 
Table 1. Systematic review data of published cases of carcinoma of the cervix associated with procidentia.

\begin{tabular}{|c|c|c|c|c|c|c|}
\hline Author & Age & Histology & Stage & Surgery & Chemotherapy/Radiotherapy & Outcome \\
\hline $\begin{array}{l}\text { Borgas de Silva } \\
2001[8]\end{array}$ & 69 & $\begin{array}{l}\text { Squamous cell } \\
\text { carcinoma }\end{array}$ & $\| \mathrm{A}$ & $\begin{array}{l}\text { Radical vaginal hysterectomy } \\
\text { with bilateral salpingoo- } \\
\text { ophorectomy and vaginal, } \\
\text { parametrial resection }\end{array}$ & $\begin{array}{l}\text { External pelvic radiotherapy at a } \\
\text { total dose of } 5,000 \text { cGy fractionated } \\
\text { over a period of } 5 \text { weeks }\end{array}$ & $\begin{array}{l}\text { Free of disease at } 2 \text { years, lost } \\
\text { to follow-up since }\end{array}$ \\
\hline $\begin{array}{l}\text { Borgas de Silva } \\
2001\end{array}$ & 73 & $\begin{array}{l}\text { Squamous cell } \\
\text { carcinoma }\end{array}$ & IIA & Radical vaginal hysterectomy & $\begin{array}{l}\text { External pelvic radiotherapy at a } \\
\text { total dose of } 5,000 \mathrm{cGy} \text { fractionated } \\
\text { over a period of } 5 \text { weeks }\end{array}$ & $\begin{array}{l}\text { Alive with no signs of recur- } \\
\text { rence } 2 \text { years after surgery }\end{array}$ \\
\hline $\begin{array}{l}\text { Cabrera } 2010 \\
{[9]}\end{array}$ & 54 & $\begin{array}{l}\text { Clear cell ad- } \\
\text { enocarcinoma }\end{array}$ & IB2 & $\begin{array}{l}\text { Laparoscopic radical } \\
\text { hysterectomy with bilateral } \\
\text { salpingo-oophorectomy, } \\
\text { pelvic lymphadenectomy } \\
\text { and para-aortic lymph node } \\
\text { sampling }\end{array}$ & $\begin{array}{l}\text { Adjuvant chemoradiotherapy, } 46 \mathrm{~Gy} \text {. } \\
\text { Chemotherapy based } \\
\text { on 5-fluorouracil plus cisplatin }\end{array}$ & $\begin{array}{l}\text { Alive with no signs of relapse } \\
10 \text { months after treatment }\end{array}$ \\
\hline $\begin{array}{l}\text { Cheung } 2012 \\
{[10]}\end{array}$ & 77 & $\begin{array}{l}\text { Squamous cell } \\
\text { carcinoma }\end{array}$ & IIB & Total excision & $\begin{array}{l}\text { Post-operative tomoradiation of } \\
6,000 \text { cGy in } 30 \text { fractions to the } \\
\text { pelvis }\end{array}$ & Not reported \\
\hline $\begin{array}{l}\text { Chung } 2018 \\
{[11]}\end{array}$ & 67 & $\begin{array}{l}\text { Squamous cell } \\
\text { carcinoma }\end{array}$ & IIA2 & $\begin{array}{l}\text { Total vaginal hysterectomy, } \\
\text { exploratory laparotomy, } \\
\text { bilateral Salpingooophorec- } \\
\text { tomy, cancer staging, and } \\
\text { intraabdominal uterosacral } \\
\text { ligament suspension }\end{array}$ & Adjuvant chemoradiation & Not reported \\
\hline $\begin{array}{l}\text { Dane } 2009 \\
{[12]}\end{array}$ & 89 & $\begin{array}{l}\text { Squamous } \\
\text { cell carcinoma } \\
\text { (Verrucous) }\end{array}$ & IIA & $\begin{array}{l}\text { Resection of the vagina and } \\
\text { parametria }\end{array}$ & Did not receive & $\begin{array}{l}\text { Free of disease at } 6 \text { months of } \\
\text { follow up }\end{array}$ \\
\hline $\begin{array}{l}\text { Dawkins } 2018 \\
{[13]}\end{array}$ & 72 & $\begin{array}{l}\text { Squamous cell } \\
\text { carcinoma }\end{array}$ & IIA2 & $\begin{array}{l}\text { Perineorrhaphy, cystocele, } \\
\text { enterocele repair, Gellhorn } \\
\text { pessary placement }\end{array}$ & $\begin{array}{l}\text { External beam radiation therapy, } \\
\text { vaginal brachytherapy. Chemothera- } \\
\text { py with cisplatin }\end{array}$ & Free of disease at 15 months \\
\hline $\begin{array}{l}\text { El-Abbassi } \\
2017[14]\end{array}$ & 79 & $\begin{array}{l}\text { Squamous cell } \\
\text { carcinoma }\end{array}$ & IIIB & Did not undergo surgery & Palliative Chemotherapy & Dead of Disease at 3 months \\
\hline $\begin{array}{l}\text { Kriplani } 1995 \\
{[15]}\end{array}$ & 60 & $\begin{array}{l}\text { Squamous cell } \\
\text { carcinoma }\end{array}$ & IIIB & Did not undergo surgery & $\begin{array}{l}\text { Radiotherapy for a total of } 50 \text { Grays, } \\
27 \text { fractions over } 5.5 \text { weeks }\end{array}$ & $\begin{array}{l}\text { Subsequent visit } 2 \text { months after } \\
\text { completion of radiotherapy } \\
\text { did not reveal any disease. } \\
\text { Intracavitary radiotherapy was } \\
\text { planned but the patient did not } \\
\text { return for follow-up }\end{array}$ \\
\hline $\begin{array}{l}\text { Loizzi } 2010 \\
{[16]}\end{array}$ & 86 & $\begin{array}{l}\text { Squamous cell } \\
\text { carcinoma }\end{array}$ & IIA & $\begin{array}{l}\text { Vaginal hysterectomy with } \\
\text { upper vaginectomy in spinal } \\
\text { anesthesia due to poor } \\
\text { performance status }\end{array}$ & Did not receive & $\begin{array}{l}\text { Died of pulmonary embolism } 20 \\
\text { days after surgery }\end{array}$ \\
\hline $\begin{array}{l}\text { Pardal } 2015 \\
{[17]}\end{array}$ & 74 & $\begin{array}{l}\text { Squamous cell } \\
\text { carcinoma }\end{array}$ & IIIB & $\begin{array}{l}\text { Vaginal hysterectomy plus } \\
\text { open bilateral iliopelvic } \\
\text { lymphadenectomy }\end{array}$ & $\begin{array}{l}\text { Pelvic external beam radiotherapy } \\
50 \mathrm{~Gy} / 25 \mathrm{~F} \text { plus vaginal brachyther- } \\
\text { apy } 3 \times 7 \mathrm{~Gy} \text { ) and chemotherapy with } \\
\text { cisplatin ( } 40 \mathrm{mg} / \mathrm{m}^{2} / \text { weekly). Dis- } \\
\text { ease progressed, palliative therapy } \\
\text { with paclitaxel ( } 175 \mathrm{mg} / \mathrm{m}^{2} \text { ) plus } \\
\text { carboplatin (AUC5) every } 3 \text { weeks. }\end{array}$ & $\begin{array}{l}\text { Twelve months after the } \\
\text { diagnosis the patient was } \\
\text { admitted in the hospital due to } \\
\text { an insidious onset of altered } \\
\text { mental status and end-life care } \\
\text { performed }\end{array}$ \\
\hline
\end{tabular}


Table 1. Systematic review data of published cases of carcinoma of the cervix associated with procidentia.

\begin{tabular}{|c|c|c|c|c|c|c|}
\hline $\begin{array}{l}\text { Reimer } 2008 \\
{[18]}\end{array}$ & 73 & $\begin{array}{l}\text { Squamous cell } \\
\text { carcinoma }\end{array}$ & IIA & $\begin{array}{l}\text { Total vaginal hysterectomy } \\
\text { and partial colpectomy with } \\
\text { colpocleisis }\end{array}$ & $\begin{array}{l}\text { Combined pelvic radiotherapy with } \\
\text { cisplatin }\end{array}$ & $\begin{array}{l}\text { After five years of follow up, } \\
\text { no disease recurrent and pelvic } \\
\text { floor stability }\end{array}$ \\
\hline $\begin{array}{l}\text { Reisenauer } \\
2017 \text { [19] }\end{array}$ & 81 & $\begin{array}{l}\text { Squamous cell } \\
\text { carcinoma }\end{array}$ & IIA & $\begin{array}{l}\text { Vaginal radical hysterectomy, } \\
\text { salpingo-oophorectomy, } \\
\text { laparoscopic sentinel pelvic } \\
\text { lymphadenectomy, Le Fort } \\
\text { colpoclesis }\end{array}$ & Did not receive & Not reported \\
\hline $\begin{array}{l}\text { Vieillefosse } \\
2014[20]\end{array}$ & 87 & $\begin{array}{l}\text { Squamous cell } \\
\text { carcinoma }\end{array}$ & IB2 & $\begin{array}{l}\text { Rouhier proceure: Modi- } \\
\text { fied LeFort colopcleisis with } \\
\text { hysterectomy }\end{array}$ & $\begin{array}{l}\text { External pelvic radiotherapy (dosing } \\
\text { not reported) }\end{array}$ & Free of disease at 1 year \\
\hline $\begin{array}{l}\text { Cabanis } 1963 \\
{[21]}\end{array}$ & 68 & $\begin{array}{l}\text { Squamous cell } \\
\text { carcinoma }\end{array}$ & IIB & --- & --- & $\begin{array}{l}\text { Alive with disease at } 8 \text { months, } \\
\text { lung metastasis }\end{array}$ \\
\hline
\end{tabular}

The mean age at diagnosis among the reports is 74.4, ranging from 54 to 89 years of age. 13 of the 14 cases were squamous cell carcinoma of the cervix, one with verrucous features and one reported case of clear cell adenocarcinoma. Two cases presented with Stage I (14.2\%), nine with Stage II (64.2\%), three with Stage III (21.4\%) and none with Stage IV. All had complete uterovaginal prolapse. Two cases did not undergo surgery (both stage IIIB), the third reported case of stage IIIB in Pardal et al [17] underwent total vaginal hysterectomy and partial colpectomy with colpoclesis. Eight cases underwent vaginal hysterectomy (57.1\%), one underwent laparoscopic radical hysterectomy (7.1\%). Three cases underwent lymphadenectomy (21.4\%). Five surgeries addressed the pelvic organ prolapse (35.7\%); one case performed perineorrhaphy, cystocele, enterocele and Gellhorn pessary placement, one case with intraabdominal uterosacral ligament suspension, and colpoclesis performed in three. Three cases did not receive chemotherapy or radiation. Ten cases received pelvic radiotherapy (71.4\%), four received a combination of chemoradiation (28.5\%) - all with cisplatin and one with 5-fluorouracil plus cisplatin. Patient outcomes were mixed. Seven patients were free of disease throughout follow-up (mean 21.5 months, ranging 6-60 months of follow-up reported). There were three deaths reported, two from disease (14.2\%) at 3 and 12 months, and one from pulmonary embolism 20 days following surgery. Three cases did not report on the outcome and one case was last to follow up at 2 months.

Currently, there is no evidence-based management for cervical cancer associated with uterovaginal prolapse. Most reported cases in the literature suggest a radical vaginal hysterectomy with bilateral iliopelvic lymphadenectomy, external pelvic radiation and chemotherapy [17]. The decision for management must consider staging, the extent of spread, degree of procidentia and cystocele-rectocele involvement with risk of visceral injury following radiotherapy. The patient described above underwent PD-L1 testing with an attempt at alternative immunotherapy in hopes to optimise treatment. In June, 2018, the Food and Drug Administration approved pembrolizumab (Keytruda) with advanced, PD-L1-positive cervical cancer with progression while on or following chemotherapy. This decision was based on data from the Phase II KEYNOTE-158 trial which demonstrated an overall response rate of $17 \%$ ( $27 \%$ among patients with $\geq 27$ weeks of follow-up) in advanced cervical squamous cell carcinomas [22]. This case further demonstrates the need for more literature surrounding cervical cancer with uterine invasion, especially associated with pelvic organ prolapse, in order to determine the most effective therapies.

\section{Conclusion}

Overall, cervical cancer with invasion of uterovaginal prolapse is exceedingly rare in developed countries. There have been a total of 13 reported cases in the literature of cervical cancer association with uterovaginal prolapse between 1990 and 2017 , each with various treatments and outcomes. There are no current management guidelines for cervical cancer with invasion of pelvic organ prolapse. As demonstrated from this study, management varies widely across the literature. However, a majority of cases underwent vaginal hysterectomy (57.1\%) and pelvic radiotherapy (71.4\%). The case reported above demonstrates the need to pursue additional biomarkers and therapies among this rare population. Especially, given the recent approval of pembrolizumab for advanced, PD-L1-positive cervical cancer with progression while on or following chemotherapy, PD-L1 testing and immunotherapy options should be considered. Further studies are necessary to further identify effective treatment strategies of uterovaginal prolapse associated with carcinoma of the cervix. 


\section{Conflicts of interest}

The authors have no conflicts of interest to disclose.

\section{Funding declaration}

This study received no funding.

\section{Author contributions}

Ryan M Kahn M.D., M.H.S: project development; data collection or management; data analysis; manuscript writing/editing.

Kiersten Craig M.D: project development; data collection or management; data analysis; manuscript writing/editing.

Tanaka J Dune M.D: project development; data collection or management; data analysis; manuscript writing/editing.

Kevin Holcomb: project development; data collection or management; data analysis; manuscript writing/editing.

Eloise Chapman-Davis M.D.: project development; data collection or management; data analysis; manuscript writing/editing.

Melissa K Frey M.D.: project development; data collection or management; data analysis; manuscript writing/editing.

\section{References}

1. Cervical cancer. Estimated incidence, mortality and prevalence worldwide in 2012 [http://globocan.iarc.fr/Pages/fact_sheets_cancer. aspx]

2. WHO/ICO Information Center of HPV and Cervical Cancer (HPV Information Center). Human Papillomavirus and Related Cancers in the World. Summary Report 2010 [http://www.who.int/hpvcentre/en]

3. Torre LA, Bray F, and Siegel RL, et al (2015) Global cancer statistics, 2012 CA Cancer J Clin 65(2) 87-108 https://doi.org/10.3322/ caac.21262 PMID: 25651787

4. Key Statistics for Cervical Cancer (2018) (Atlanda: American Cancer Society) [www.cancer.org/cancer/cervical-cancer/about/key-statistics.html]

5. Maher C, Feiner B, and Baessler K, et al (2013) Surgical management of pelvic organ prolapse in women Cochrane Database Syst Rev (4) Cd004014 PMID: 23633316

6. Liberati A, Altman DG, and Tetzlaff J, et al (2009) The PRISMA statement for reporting systematic reviews and meta-analyses of studies that evaluate healthcare interventions: explanation and elaboration BMJ 339 b2700 https://doi.org/10.1136/bmj.b2700 PMID: 19622552 PMCID: 2714672

7. Matsuo K, Machida H, and Blake EA, et al (2017) Significance of uterine corpus tumor invasion in early-stage cervical cancer Eur J Surg Oncol 43(4) 725-734 https://doi.org/10.1016/j.ejso.2017.01.017 PMID: 28215507

8. da Silva BB, da Costa Araújo R, and Filho CP, et al (2002) Carcinoma of the cervix in association with uterine prolapse Gynecol Oncol 84(2) 349-350 https://doi.org/10.1006/gyno.2001.6503 PMID: 11812100

9. Cabrera S, Franco-Camps S, and García A, et al (2010) Total laparoscopic radical hysterectomy for cervical cancer in prolapsed uterus Arch Gynecol Obstet 282 63-67 https://doi.org/10.1007/s00404-010-1472-7 PMID: 20405294 PMCID: 7103181

10. Cheung WK, Ho MP, and Wei MC, et al (2012) Association between uterine prolapse and cervical squamous cell carcinoma in an elderly adult J Am Geriatr Soc 60(9) 1775-1777 https://doi.org/10.1111/j.1532-5415.2012.04139.x PMID: 22985150 
11. Chung CP, Lee SJ, and Wakabayashi MT (2018) Uterine and cervical cancer with irreducible pelvic organ prolapse Am J Obstet Gynecol 219(6) 621-622 https://doi.org/10.1016/j.ajog.2018.05.021 PMID: 29852160

12. Dane B, Dane C, and Erginbas M, et al (2009) Verrucous carcinoma of the cervix in a case with uterine prolapse Ann Diagn Pathol 13(5) 344-346 https://doi.org/10.1016/j.anndiagpath.2009.02.005 PMID: 19751912

13. Dawkins JC, Lewis GK, and Toy EP (2018) Cervical cancer complicating pelvic organ prolapse, and use of a pessary to restore anatomy for optimal radiation: a case report Gynecol Oncol Rep 26 14-16 https://doi.org/10.1016/j.gore.2018.08.004 PMID: 30148199 PMCID: 6106706

14. El-Abbassi S, El-Majjaoui S, and El-Kacemi H, et al (2017) Complete genital prolapse with cervix carcinoma: a case report and literature review Arch Can Res 52 https://doi.org/10.21767/2254-6081.1000141

15. Kriplani A, Relan S, and Kumar L, et al (1995) Incarcerated procidentia: a rare complication of carcinoma cervix Aust N Z J Obstet Gynaecol 35(4) 463-464 https://doi.org/10.1111/j.1479-828X.1995.tb02170.x PMID: 8717582

16. Loizzi V, Cormio G, and Selvaggi L, et al (2010) Locally advanced cervical cancer associated with complete uterine prolapse Eur J Cancer Care (Engl) 19(4) 548-550 https://doi.org/10.1111/j.1365-2354.2008.01010.x

17. Pardal C, Correia C, and Serrano P (2015) Carcinoma of the cervix complicating a genital prolapse BMJ Case Rep 2015. https://doi. org/10.1136/bcr-2015-209580

18. Reimer D, Sztankay A, and Steppan I, et al (2008) Cervical cancer associated with genital prolapse-a brief review of the literature and long-term results of successful treatment with radiochemotherapy and surgery in a very frail patient Eur J Gynaecol Oncol 29 272-275

19. Reisenauer C, Wallwiener D, Brucker SY, et al (2017) Pelvic organ prolapse stage IV and cervical cancer FIGO Ila Arch Gynecol Obstet 295(6) 1303-1304 https://doi.org/10.1007/s00404-017-4377-x PMID: 28444514

20. Vieillefosse S, Thubert T, and Trichot C, et al (2014) Cancer du col et prolapses génital exteriorize Progrès en urologie 24 533-534 https:// doi.org/10.1016/j.purol.2014.04.003

21. Cabaniss CM and Crocker CL, Carcinoma of the prolapsed cervical stump. Report of a case Obstet Gynecol $22606-609$ PMID: 14082280

22. Schellens JHM, Marabelle A, and Zeigenfuss S, et al (2017) Pembrolizumab for previously treated advanced cervical squamous cell cancer: preliminary results from the phase 2 KEYNOTE-158 study J Clin Oncol 35(15_suppl) 5514 https://doi.org/10.1200/JCO.2017.35.15_ suppl.5514 